\title{
Role of Pannexin-1 hemichannels and purinergic receptors in the pathogenesis of human diseases
}

\author{
Stephani Velasquez ${ }^{1,2}$ and Eliseo A. Eugenin ${ }^{1,2 *}$ \\ ${ }_{1}^{1}$ Public Health Research Institute, Rutgers the State University of New Jersey, Newark, NJ, USA \\ ${ }^{2}$ Department of Microbiology and Molecular Genetics, Rutgers New Jersey Medical School, Rutgers the State University of New Jersey, Newark, NJ, USA
}

\section{Edited by:}

Mauricio Antonio Retamal,

Universidad del Desarrollo, Chile

Reviewed by:

Aida Salameh, Heart Centre

University of Leipzig, Germany

Juan Andrés Orellana, Pontificia

Universidad Católica de Chile, Chile

Kurt Alex Schalper, Yale University

School of Medicine, USA

\section{*Correspondence:}

Eliseo A. Eugenin, Public Health

Research Institute and Department

of Microbiology and Molecular

Genetics, Rutgers New Jersey

Medical School, Rutgers The State

University of New Jersey, 225

Warren St./RBL 2220, Newark, NJ

08901, USA

e-mail: eliseo.eugenin@rutgers.edu
In the last decade several groups have determined the key role of hemichannels formed by pannexins or connexins, extracellular ATP and purinergic receptors in physiological and pathological conditions. Our work and the work of others, indicate that the opening of Pannexin-1 hemichannels and activation of purinergic receptors by extracellular ATP is essential for HIV infection, cellular migration, inflammation, atherosclerosis, stroke, and apoptosis. Thus, this review discusses the importance of purinergic receptors, Panx-1 hemichannels and extracellular ATP in the pathogenesis of several human diseases and their potential use to design novel therapeutic approaches.

\section{INTRODUCTION}

In recent years it has become evident that pannexin (Panx)-1 hemichannels in concert with extracellular adenosine triphosphate (ATP) and purinergic receptors are involved in several physiological and pathological conditions. Recent evidence suggests the participation of Panx-1 hemichannels, extracellular ATP and purinergic receptors in the coordination of events such as cellular activation, apoptosis, stress signals, secretion of inflammatory cytokines, and HIV replication have been explored (Pelegrin, 2008; Schenk et al., 2008; Chekeni et al., 2010; Woehrle et al., 2010; Qu et al., 2011; Seror et al., 2011; Orellana et al., 2013). This review will describe these interactions in the context of several human diseases.

The Panx family consists of three members, Panx-1, -2 , and -3 (Baranova et al., 2004). Panx-1 is ubiquitously expressed (Scemes et al., 2009). Panx-2 is mainly expressed in the central nervous system (CNS), while Panx-3 is localized in osteoblasts, synovial fibroblasts and chondrocytes (Barbe et al., 2006; Ray et al., 2006). Originally, it was speculated that Panx hemichannels could form gap junction channels between adjacent cells (Bruzzone et al., 2003, 2005; Bruzzone and Dermietzel, 2006). However, current evidence suggests that Panxs cannot form intercellular channels (Boassa et al., 2007). Asparagine residues found on the extracellular domains of Panx are glycosylated and therefore make docking between two Panxs highly unlikely (Boassa et al., 2007; Penuela et al., 2007).

Panxs are structurally similar to connexins (Cxs), although they share no sequence homology. Panx consist of a cytosolic $\mathrm{N}$-terminal domain, four transmembrane domains with two extracellular loops and a cytosolic C-terminal domain (Boassa et al., 2007; Penuela et al., 2007). Panxs form large pore channels located on the plasma membrane, which are known to open during membrane depolarization, by changes in intracellular $\mathrm{Ca}^{2+}$ signaling, vasodilation, vasoconstriction, taste sensation, airway defense, learning/memory, cellular differentiation, cell death and during innate, and adaptive immune responses (Chekeni et al., 2010; MacVicar and Thompson, 2010; Prochnow et al., 2012). Upon opening of these hemichannels small signaling molecules such as ATP are released to the extracellular space, which then signal through surface receptors including purinergic receptors.

Purinergic receptors are divided into two groups, Adenosine receptors (ARs) for adenosine and P2 receptors for ATP/ADP receptors (Fredholm et al., 1994; Ralevic and Burnstock, 1998). P2 receptors are subdivided into ionotropic $\mathrm{P} 2 \mathrm{X}$ and metabotropic P2Y receptors. P2X receptors are ligand gated ion channels that form trimeric structures using individual subunits ( $\mathrm{P} 2 \mathrm{X} 1, \mathrm{P} 2 \mathrm{X} 2$, P2X3, P2X4, P2X5, P2X6, and P2X7) (Fredholm et al., 1994; Ralevic and Burnstock, 1998). P2Y receptors are G-protein coupled receptors with eight subtypes (P2Y1, P2Y2, P2Y4, P2Y6, $\mathrm{P} 2 \mathrm{Y} 11, \mathrm{P} 2 \mathrm{Y} 12, \mathrm{P} 2 \mathrm{Y} 13, \mathrm{P} 2 \mathrm{Y} 14)$. Purinergic receptor signaling is fundamental in many cellular processes such as platelet aggregation, exocrine and endocrine secretion, endothelial-mediated vasodilation, nociceptive mechanosensory transduction, neuromodulation, neuroprotection, cell proliferation, differentiation, migration, embryological development, wound healing, inflammation, and cytokine secretion (Abbracchio and Burnstock, 1998; Burnstock and Knight, 2004; Burnstock and Verkhratsky, 2010; Burnstock, 2012). Upon release of ATP into the extracellular space, several enzymes degrade ATP into ADP, AMP and 
adenosine, which also signals through purinergic receptors and adenosine receptors.

ARs (A1, A2A, A2B, and A3) were initially classified as P1 receptors until it was discovered that their agonist was adenosine (Fredholm et al., 1994; Junger, 2011). As indicated above, the production of extracellular adenosine is achieved by hydrolyzing ATP in a stepwise manner by ectonucleotidases (Yegutkin, 2008). These enzymes include the Ecto-nucleotide pyrophosphatase/phosphodiesterase (E-NPP) family comprised of three enzyme subtypes, which hydrolyses ATP to AMP, and Ectonucleoside triphosphate diphosphydrolase (E-NTDPase) family comprised of eight enzyme subtypes, which can hydrolyze ATP to ADP or AMP. Finally, Ecto-5'-nucleotidase/ CD73 in tandem with CD38 can hydrolyze AMP to adenosine, which then activates the ARs (Yegutkin, 2008; Junger, 2011). In Figure 1 we summarized the interaction between Panx-1 hemichannels, purinergic receptors, adenosine receptor, as well as the extracellular metabolism of ATP (Figure 1). In the next sections we will discuss the involvement of this complex in several human diseases.

\section{PURINERGIC RECEPTORS, PANX-1 HEMICHANNELS AND THEIR INVOLVEMENT IN ISCHEMIC STROKE}

According to the World Health Organization (WHO), 15 million people suffer stroke worldwide each year, resulting in 5 million deaths and another 5 million survivors that are permanently disabled (www.WHO.int). Ischemic stroke results from a permanent or transient decrease in cerebral blood flow. This decrease in blood flow is usually caused by the obstruction of a cerebral artery by an embolus or local thrombosis (Katsura et al., 1994; Martin et al., 1994; Dirnagl et al., 1999). Brain tissue requires a high intake of glucose and oxygenation for proper cerebral function. The restriction of cerebral blood flow impairs the delivery of glucose and oxygen and consequently leads to tissue damage by mechanisms dependent on excitotoxicity, peri-infarct depolarizations, inflammation and programmed cell death (Katsura et al., 1994; Martin et al., 1994; Dirnagl et al., 1999).

Thompson et al. demonstrated a connection between Panx-1 hemichannels and ischemia using acutely isolated hippocampal neurons in which oxygen and glucose deprivation (OGD) resulted in opening of Panx-1 hemichannels (Thompson et al., 2006). Blocking NMDA (N-methyl-D-aspartate), AMPA (2amino-3-[5-methyl-3-oxo-1,2-oxazol-4-yl] propanoic acid) and P2X7 receptors failed to modify the large anoxic depolarization activated by OGD, which corresponded to opening of Panx1 hemichannels. Therefore, the mechanism by which Panx-1 hemichannels are opened during OGD was thought to be independent from ligand-gated receptors (Thompson et al., 2006). Recent evidence suggests that anoxia induces NMDA receptor



FIGURE 1 | A schematic representation of the elements involved in the release of ATP by opening of Panx-1 hemichannels and subsequent activation of purinergic signaling. Pathological or physiological stimuli result in the opening of Panx-1 hemichannels promoting the release of ATP from the cell. ATP/ADP/AMP could then bind to $\mathrm{P} 2 \mathrm{X}$ and $\mathrm{P} 2 \mathrm{Y}$ receptors. Ecto-nucleoside triphosphate diphosphydrolase (E-NTDPase) including ecto-ATPase and ATP-diphosphohydrolase promotes the hydrolysis of ATP to ADP or from ADP to AMP (2). Ecto-nucleotide pyrophosphatase/phosphodiesterase (E-NPP) hydrolysis ATP to AMP (1). AMP is further hydrolyzed by Ecto-5'-nucleotidase/ CD73 (3) which promotes the formation of adenosine. Adenosine then activates adenosine receptors (AR). 
activation, which activates Src kinases, that participates in the opening of Panx-1 hemichannels (Weilinger et al., 2012). This suggests a signaling pathway involving the coupling of NMDA receptors using Src Kinases to Panx-1 hemichannels. Furthermore overstimulation of NMDA receptors activates the opening of Panx-1 hemichannels in neurons (Thompson et al., 2008). However, another study demonstrated that inhibiting glutamate receptors of hippocampal pyramidal slices prevented anoxic depolarization and that Panxl hemichannels did not generate a large inward current associated with anoxic depolarization (Madry et al., 2010). Therefore, future studies are required to clarify the participation of Panx-1 hemichannels in response to anoxia/ischemia.

ATP is a neurotransmitter that mediates communication between CNS cells, including astrocytes and neurons. Initially, it was believed that the mechanism by which ATP was released from astrocytes involved Connexin43 (Cx43) hemichannels. However, experiments conducted using wild type, $\mathrm{Cx} 43$ null, and Panx1 knocked down astrocytes provided evidence indicating that downregulation of Panx-1 prevented the release of ATP from astrocytes (Iglesias et al., 2009). Downregulation of Cx43 has no affect on the release of ATP from astrocytes. In contrast, experiments using conditional $\mathrm{Cx} 43$ knockout demonstrated that ATP release and recruitment of microglia/macrophages following injury was reduced and the recovery of the animals was improved, suggesting a role for $\mathrm{Cx} 43$ hemichannels in inflammation but also in recovery (Huang et al., 2012). Orellana et al. demonstrated that under hypoxic conditions astrocytes release ATP and glutamate activating neuronal Panx-1 hemichannels via P2X and NMDA receptors resulting in neuronal death (Orellana et al., 2011). This study demonstrates that neurons could be protected from ischemia-associated damage by blocking NMDA/P2X receptors as well as Panx-1 hemichannels (Orellana et al., 2011).

Furthermore experiments conducted in the double Panx-1 and Panx-2 knockout mice subjected to permanent right middle cerebral artery occlusion (MCAO) demonstrated that Panx channels contributed to ischemic brain injury in vivo (Bargiotas et al., 2011). The double knockout mice subjected to MCAO demonstrated improved neurological deficit, reduced movement latency and infarct size as compared to the wild type (Bargiotas et al., 2011). Single knockouts of either Panx-1 or Panx-2 did not differ in ischemic brain injury from wild type; however, Panx-2 knockout mice were partially protected from ischemic injury. These data suggests that Panx-1 and Panx-2 work together to regulate response to injury.

Ischemia induces astrocytes to release ATP, which rapidly activates microglia resulting in the formation of a barrier between the healthy and injured tissue in order to promote repair (Davalos et al., 2005; Nimmerjahn et al., 2005). Moreover, an excess release of nucleotides can result in accelerated neurodegeneration (Di Virgilio et al., 2009). An excessive level of extracellular ATP in oligodendrocytes induces a rise in cytosolic $\mathrm{Ca}^{2+}$ by activating P2 receptors and P2Y7 receptors (Kirischuk et al., 1995; James and Butt, 2001). Using primary cultures of oligodendrocytes it was demonstrated that OGD induced the release of ATP and blocking of $\mathrm{P} 2 \mathrm{X} 7$ receptors using periodate oxidized ATP
(oATP) or Brilliant Blue G (BBG) reduces the ischemic-induced ionic imbalance. In addition, reduction in opening of Panx hemichannels using blockers such as mefloquine and flufenamic acid reduced extracellular ATP levels after OGD attenuating ischemic damage. These data indicates that OGD opens Panx hemichannels inducing the release of ATP which then activates $\mathrm{P} 2 \mathrm{X} 7$ receptors causing oligodendrocytes failure, myelin damage and axon dysfunction (Domercq et al., 2010).

Furthermore, elevations in the expression of several $\mathrm{P} 2$ receptors (P2X1, P2X2, P2X4, P2X7, and P2Y4) during ischemia have been demonstrated suggesting increased sensitivity of neurons to extracellular concentration of ATP (Cavaliere et al., 2002, 2003, 2007). Using spontaneously hypertensive rats (SHR) subjected to MCAO Lammer et al. demonstrated that inhibition of P2 receptors by pyridoxalphosphate-6-azophenyl-2', 4'-disulfonate (PPADS) improved the recovery of the cortical electrophysiological and motor functions (Lammer et al., 2006, 2011). PPADS does not pass through the blood brain barrier; therefore, the rats were infused by intracerebroventricular administration for 7 days after MCAO. Furthermore, analysis of motor coordination demonstrated that blockade of $\mathrm{P} 2$ receptors by PPADS resulted in improved motor recovery when compared to non-PPADS treated rats subjected to MCAO (Lammer et al., 2011). Thus, opening of Panx-1 hemichannels and activation of $\mathrm{P} 2$ receptors play a major role in the pathogenesis of ischemia and blocking or knocking down these hemichannels/receptors could provide additional therapeutic interventions to reduce damage and to improve recovery in response to ischemic events.

\section{PANX HEMICHANNELS, PURINERGIC RECEPTORS AND INFLAMMATION}

Tissue damage causes the release of ATP from injured cells, resulting in $\mathrm{P} 2$ receptor mediated purinergic signaling and the initiation of inflammation (Bours et al., 2006; Kanneganti et al., 2006; Mariathasan et al., 2006). During this process in both immune and parenchymal cells, hemichannels are open in concert with activation of purinergic receptors to control cellular migration, inflammation, and damage.

As indicated above an essential aspect of inflammation is the migration of inflammatory cells into areas of injury. Cellular migration requires mechanisms to allow orientated movement including sensing changes in the chemoattractant gradient, activation of G-protein coupled receptors, and downstream signaling resulting in cytoskeletal rearrangement leading to movement toward the chemotactic signal. Recent evidence suggests that Panx-1 hemichannels and P2X7 could initiate an intracellular signaling cascade which, results in rearrangement of the F-actin microfilament network in C6 glioma cells causing the assembly of large tumor cell aggregates (Bao et al., 2012). A similar actin microfilament rearrangement as mentioned above is a critical step in cellular migration. Intracellular ATP is released through Panx-1 hemichannels and then binds to the P2X7 receptor (see Figure 1), which causes an increase in intracellular calcium resulting in actin microfilament organization (Cotrina et al., 1998; Suadicani et al., 2006). Current evidence suggests that the release of ATP by a Panx-1 hemichannel mediated mechanism from apoptotic cells function as "Find me signals" in order to recruit monocytes to 
areas of damage (Chekeni et al., 2010). Our laboratory demonstrated that chemokines that bind to CCR 5 or CXCR4 transiently open Panx-1 hemichannels in T lymphocytes, suggesting that these channels also play a key role in surveillance and inflammation. Thus our work and the work of others propose that Panx-1 hemichannels, extracellular ATP and purinergic receptors are essential in immune surveillance and inflammation.

Migration in a chemotactic gradient requires excitatory signals at the front of the cell and inhibitory signals at the back of the cell (Berzat and Hall, 2010). In this context ATP released by Panx-1 hemichannels stimulates the P2Y2 receptors, which provides the excitatory signal at the front of the cell (Chen et al., 2006, 2010). Bao et al. demonstrated that Panx-1 hemichannels provides the ligand for the adenosine $\mathrm{A} 2 \mathrm{~A}$ receptors that plays a role in the inhibitory signal at the back of the cell (Bao et al., 2013). Resting neutrophils had a uniform distribution across the cell of $\mathrm{A} 2 \mathrm{~A}$ receptors and polarized cells had the $\mathrm{A} 2 \mathrm{~A}$ receptors redistributed to the back of the cell where they provided the inhibitory signal. Inhibition of Panx-1 hemichannels blocked A2A receptor stimulation preventing the accumulation of cAMP, impairing the polarization and migration of neutrophils in a chemotactic gradient (Bao et al., 2013). These results suggest that chemoattractant receptors require opening of Panx-1 hemichannels in order to provide excitatory and inhibitory signals for efficient chemotaxis of neutrophils.

Inflammasomes are large multiprotein complexes leading to caspases-1-activated maturation of IL-1 $\beta$ and IL-18. The NLRP3 inflammasome is the most studied inflammasome containing NLRP3 as a scaffold protein (Schroder and Tschopp, 2010; Davis et al., 2011). NLRP3 inflammasomes are activated via dangerassociated molecular patterns (DAMPs) such as extracellular ATP, which act through P2X7 receptors (Lich et al., 2006; Meylan et al., 2006; Said-Sadier and Ojcius, 2012). There are several proposed mechanisms, which induce NLRP3 inflammasome activation such as, reactive oxygen species (ROS) production and apoptosis (Said-Sadier and Ojcius, 2012). Cell induced ROS production and immune activation, have been shown to induce caspase- 1 activation (Cruz et al., 2007; Said-Sadier and Ojcius, 2012). Hung et al. demonstrated that activation of P2X4 and $\mathrm{P} 2 \mathrm{X} 7$ in response to ATP released by Panx-1 hemichannels contributed to ATP induced ROS production and inflammasome activation in gingival epithelial cells (Hung et al., 2013). Inhibitors of P2X4, P2X7, and Panx-1 significantly reduced ATP dependent production of ROS. Reduced expression of P2X4, P2X7, and Panx-1 using siRNA demonstrated that both purinergic receptors and Panx-1 hemichannel were required for ATP-induced ROS production in primary and immortalized gingival epithelial cells (Hung et al., 2013). Furthermore, recent evidence identifies that the NLRP3 inflammasome is activated during the phagocytosis of dying autophagic cells. This mechanism involves the release of ATP through Panx-1 hemichannels of the dying autophagic cell, P2X7 receptor activation and potassium efflux (Ayna et al., 2012).

In agreement, patients who have chronic lung inflammation such as allergic asthma or chronic obstructive pulmonary disease have enhanced extracellular ATP levels in the bronchoalveolar space, as well as in the bronchoalveolar lavage fluids (BALF) suggesting that the enhanced lung inflammation observed in these individuals may be associated with ATP dysregulation and purinergic receptor activation (Idzko et al., 2007; Lommatzsch et al., 2010). Furthermore, P2X7 receptor deficient mice have been shown to have less neutrophil airway influx and Panx1 hemichannel inhibitors partially prevent further neutrophil airway influx and cytokine production (Riteau et al., 2010). Extracellular ATP serves as a danger signal to the immune system by binding to P2X7 receptor and activating NALP3 and caspase- 1 which then leads to the maturation and release of IL$1 \beta$, eventually forming the NALP3 inflammasome (Ferrari et al., 2006; Kanneganti et al., 2006; Mariathasan et al., 2006; Sutterwala et al., 2006; Di Virgilio, 2007). Extracellular ATP induced caspase1 activation and IL-1 $\beta$ maturation requires $\mathrm{P} 2 \mathrm{X} 7$ receptor and Panx-1 hemichannel (Pelegrin and Surprenant, 2006; Locovei et al., 2007). These data further suggests the involvement of Panx1 hemichannels, purinergic receptors and extracellular ATP in inflammasome activation.

Another human disease involving Panx-1 hemichannels is inflammatory bowel diseases (IBD) including ulcerative colitis, and Crohn's disease. These diseases are chronic conditions associated with gut dysfunction resulting from alterations in the enteric nervous system leading to severe symptoms (Mawe et al., 2009). Currently not much is known about the expression of Panx-1 in the intestines. However, one study showed the expression of innexins in the gut of nematodes, which were needed for gut motility (Peters et al., 2007). Recently Gulbransen et al. showed using a mouse model of colitis that Panx-1 hemichannels are required for $\mathrm{P} 2 \mathrm{X} 7$ receptor mediated enteric neuron cell death in intestinal inflammation (Gulbransen et al., 2012). They identified that Panx-1 hemichannels play a key role in enteric neuronal damage, leading to organ dysfunction. Inhibition of Panx-1 hemichannels protects neurons and maintains proper control of the colonic muscles preserving motility (Gulbransen et al., 2012). Diezmos et al. described the expression of Panx-1 in the human colon; they also described alterations in the expression of Panx-1 in IBD patients (Diezmos et al., 2013). Panx-1 mRNA and protein was present in all layers of the human colon. There was also dense expression of Panx-1 on the submucosal and myenteric ganglia further confirming the involvement of Panx-1 in neural control of colonic motility (Diezmos et al., 2013). These findings suggest a critical role of Panx-1 hemichannels in the pathophysiology of enteric plexus damage during IBD.

As described above ATP release by opening of Panx-1 hemichannels results not only in activation of ATP receptors but also in degradation of ATP to ADP, AMP, and adenosine. CD39 and CD73 are ectonucleotidases, which degrade ATP, ADP, and AMP to adenosine (see Figure 1). These ectonucleotidases play an essential role in maintaining immune homeostasis. Regulatory $\mathrm{T}$ cells (Tregs) are mediators of inflammatory response. High levels of CD39 and CD73 are expressed on the surface of Foxp $3^{+}$Treg cells (Mandapathil et al., 2009; Schuler et al., 2011). Murine Treg cells increase CD39 activity after activation of the T cell receptor and non-activated cells had inactive CD39 (Borsellino et al., 2007). Adenosine derived from the enzymatic breakdown of ATP by CD39 and CD73 mediates a considerable portion of the antiinflammatory activities of Treg cells (Deaglio et al., 2007). Romio et al. showed that adenosine produced by Treg cells in concert 
with $\mathrm{A} 2 \mathrm{~A}$ receptors downregulated nuclear factor- $\kappa \mathrm{B}(\mathrm{NF}-\kappa \mathrm{B})$ activation in $\mathrm{T}$ effector cells, which in turn reduced the release of proinflammatory cytokines and chemokines (Romio et al., 2011). Activation of the A2A receptor on Treg cells promotes the expansion of these cells, thereby increasing immune regulation (Ohta et al., 2012). In humans $90 \%$ of Foxp $3^{+}$Treg cells also express CD39 however CD73 expression is minimal (Mandapathil et al., 2009; Dwyer et al., 2010; Mandapathil et al., 2010). Antonioli et al. speculated that CD73 may be secreted from human Treg cells and is responsible for the production of adenosine (Antonioli et al., 2013). Qiu et al. demonstrated that cells co-expressing Panx-1 hemichannel and P2Y or P2X7 receptors exposed to high levels of ATP, only transiently activates Panx-1 hemichannel (Qiu and Dahl, 2009). ATP instead of causing a positive feedback loop is actually causing a negative feedback loop and inactivating Panx1 hemichannel. This mechanism could provide another mode of immuneregulation suppressing the immune response in order to prevent damage caused by prolonged inflammation.

\section{PURINERGIC/ADENOSINE RECEPTORS AND THEIR ROLE IN ATHEROSCLEROSIS}

Atherosclerosis is a chronic inflammatory disease affecting the vessel wall and a major health issue worldwide (Koupenova et al., $2012 a, b)$. One of the major components of atherosclerosis is the formation of arterial plaques. The progression of atherosclerosis begins with the recruitment of inflammatory monocytes to the area of lipid deposition or arterial injury (Glass and Witztum, 2001; Reiss and Glass, 2006). As discussed in the previous section migration is a Panx-1 hemichannel, purinergic receptor and extracellular ATP dependent process. Infiltrating macrophages in the arterial wall take up large amounts of oxidized low-density lipoprotein (ox-LDL) becoming foam cells loaded with cholesterol (Stary et al., 1994). The accumulation of foam cells leads to the formation of fatty streaks, increase in arterial wall thickness, reduction of oxygen diffusion into the tissue and development of advanced atherosclerosis (Gessi et al., 2010; Hansson and Hermansson, 2011; Moore and Tabas, 2011; Koupenova et al., 2012a,b).

Hypoxia-inducible factor-1 (HIF-1) is a heterodimeric transcription factor comprised of $\alpha$ and $\beta$ subunits (Wang and Semenza, 1995). HIF-1 adapts cells to low oxygen partial pressure and induces target genes that influence energy metabolism, cell proliferation, hematopoiesis, vascular development, and vasotone (Semenza et al., 1994; Liu et al., 1995; Carmeliet et al., 1998; Kourembanas et al., 1998; Lacombe and Mayeux, 1998; Rose et al., 2002). Zones of hypoxia occur in the atherosclerotic plaque, a result of impaired oxygen diffusion due to the thickness of the lesion, as well as high oxygen consumption by the foam cell. Furthermore, it was demonstrated that ox-LDL induce HIF- $1 \alpha$ accumulation in human Mono-Mac-6 (MM6) macrophages (Shatrov et al., 2003). Jiang et al. investigated the gene expression profiles of cultured human U937 cells transfected by HIF- $1 \alpha$-siRNA in response to $24 \mathrm{~h}$ of exposure to ox-LDL. Their results indicated that HIF- $1 \alpha$-siRNA inhibits the development of macrophage derived foam cells with ox-LDL by inhibiting the expression of HIF-1 $\alpha$ (Jiang et al., 2007). A key function of HIF- $1 \alpha$ is the expression of vascular endothelial growth factor (VEGF). VEGF is a regulator of angiogenesis during embryogenesis, skeletal growth and reproductive functions (Ferrara et al., 2003). Together HIF-1 $\alpha$ and VEGF are involved in angiogenesis and atherogenesis. As described above the expression of HIF- $1 \alpha$ in macrophages under atherogenic conditions promotes the formation of foam cells. Foam cells, macrophages and the U937 myelomonocytic cell line were individually cultured and treated with adenosine under hypoxic conditions which resulted in the accumulation of HIF- $1 \alpha$ in all the cells (Gessi et al., 2010). When A1, A2A, A2B, and A3 receptors were knocked down using siRNA there was a reduction in the accumulation of HIF- $1 \alpha$ in the cells. In addition, the production of VEGF in foam cells was increased when adenosine was added and strongly reduced with the addition of $\mathrm{A} 2 \mathrm{~B}$, and $\mathrm{A} 3$ antagonist respectively (Gessi et al., 2010). Hypoxia stabilizes HIF-1 $\alpha$, resulting in the accumulation of adenosine (Gessi et al., 2010). Notably, it can be speculated that in this adenosine-mediated atherosclerosis mechanism, Panx-1 hemichannels may play a role in the release of intracellular ATP into the extracellular environment leading to the formation of adenosine (Figure 1).

Conversely Koupenova et al. determined that the absence of $\mathrm{A} 2 \mathrm{~B}$ adenosine receptor expression in the liver resulted in a worse atherosclerotic outcome in the double knockout mouse model of apolipoproteinE (ApoE) and A2B adenosine receptor which were fed a high fat/high cholesterol diet (Koupenova et al., 2012a,b). Lack of A2B adenosine receptor led to an elevation of plasma lipids and plaque formation. In this model the liver is responsible for contributing to the anti-atherosclerotic phenotype. Under normal conditions the liver expresses low levels of A2B adenosine receptor. However, with a high fat diet, levels of $\mathrm{A} 2 \mathrm{~B}$ receptors in the liver increase. Activation of $\mathrm{A} 2 \mathrm{~B}$ receptor in hepatocytes in vivo and in vitro causes a decrease in the transcription factor sterol regulatory element binding protein-1 (SREBP-1), which regulates lipid synthesis. Moreover, eliminating A2B adenosine receptor in the liver of the mouse model increased the levels of SREBP-1 and its downstream targets acetyl coenzyme-A carboxylase- $\alpha$ (ACC) and fatty acid synthase (FAS) resulting in upregulation of lipid synthesis. Resulting in the formation of foam cells and the development of atherosclerotic plaques. (Koupenova et al., 2012a,b).

As mentioned above the formation of an atherosclerotic plaque begins with the uptake and accumulation of cholesterol by macrophages and is also influenced by endothelial dysregulation. These atherosclerotic plaques are composed of smooth muscle cells (SMCs), which under normal physiological conditions are found in the medial layer of the artery wall. However, under atherosclerotic conditions SMCs lose their contractile element and gain the ability to replicate and migrate into the intima of the arterial wall (Gorski and Walsh, 1995). Once in the intima SMCs proliferate and begin depositing fibrotic connective tissue (Watson et al., 1998). All of these deregulated cells act as a cover for the fibrous cap that stabilizes the plaque by covering the lipid rich regions. Adenosine and ATP mediate endothelial cell growth, migration, proliferation and death (Burnstock, 2006). ATP binding of P2Y2 and/or P2Y4 stimulates SMC cell proliferation via a mitogen-activated protein kinase (MAPK) cascade contributing to the development of atherosclerosis (Hou et al., 2000). However, adenosine derived from the enzymatic breakdown of ATP by ecto- $5^{\prime}$-nucleotidase (see 
Figure 1) acts as an endogenous modulator protecting against vascular inflammation and immune cell recruitment, therefore, preventing the progression of atherosclerosis (Buchheiser et al., 2011). Adenosine in concert with $\mathrm{A} 2 \mathrm{~A}$ and $\mathrm{A} 2 \mathrm{~B}$ receptors has also been shown to stimulate endothelial cell proliferation and regulate the release of platelet-derived growth factor (PDGF) a smooth muscle mitogen from platelets (Jonzon et al., 1985; Adair, 2005).

Moreover, inflammation stimulated by accumulation of ox-LDL in the atherosclerotic plaque activates the release of cytokines and metalloproteinases resulting in degradation of the fibrous cap (Erlinge and Burnstock, 2008). These events result in a weak plaque, which can potentially rupture and release its content into the circulation. This content is highly thrombogenic and produces activation of platelets causing the formation of local thrombus occluding the artery or embolising and resulting in ischemic stroke or myocardial infarction (Erlinge and Burnstock, 2008) Pinheiro et al. demonstrated using human subcutaneous fibroblast that the release of histamine induces an increase in intracellular $\mathrm{Ca}^{2+}$ resulting in the release of ATP via Panx-1 hemichannels (Pinheiro et al., 2013). Furthermore, the release of ATP activates P2 receptors and results in fibroblast proliferation and collagen production. The principal cell type of vascular adventitia is fibroblast therefore increase proliferation of this cell type could contribute to atherosclerotic lesion progression and eventual rupture. This evidence suggests a complex mechanism, which results in plaque destabilization, and involves mast cells, histamine, P2 receptors, ATP, Panx-1 hemichannels and fibroblasts.

\section{ROLE OF PANX-1 HEMICHANNELS IN APOPTOSIS}

There are two main types of cell deaths, apoptosis and necrosis. Morphological features such as cell rounding, DNA fragmentation, externalization of phosphatidyl serine, caspase activation and the lack of an inflammatory reaction characterize apoptosis. Necrosis is characterized by swelling of organelles and plasma membrane, followed by the collapse of the plasma membrane and ending in the uncontrolled release of intracellular contents after the membrane has ruptured which leads to an inflammatory response. Intact apoptotic cells have been shown to release ATP and UTP without extrusion of additional cellular contents, suggesting the opening of relatively large membrane pores such as Cxs or Panx hemichannels during the apoptotic process (Harris, 2007; Elliott et al., 2009; Ghiringhelli et al., 2009; Scemes et al., 2009; MacVicar and Thompson, 2010).

Chekeni et al. showed in Jurkat cells that the channels involved in the release of ATP and UTP in apoptotic cells were Panx hemichannels and not Cxs hemichannels (Chekeni et al., 2010). Inhibition of these channels using 18-alpha-glycyrrhetinic acid (18AGA) or flufenamic acid (FFA), which are efficient Cxs hemichannel blockers had no effect on, the release of ATP induced by intact apoptotic cells (Chekeni et al., 2010). However, when specific Panx hemichannel blockers were used such as probenecid, the release of ATP was blocked from intact apoptotic cells. ATP is a chemoattractant for immune cells thus blocking ATP release by inhibiting Panx-1 hemichannel opening results in a decrease in monocyte recruitment (Chekeni et al., 2010).

Overexpression of Panx-1 increases the release of nucleotides during apoptosis, subsequently increasing monocyte migration.
Activation of caspases 3/7 results in opening of Panx-1 hemichannels by a mechanism that involves cleavage of the Panx-1 intracellular carboxy terminal region increasing the release of ATP and UTP which is vital for apoptosis. Using whole cell patch clamp it was determined that opening of Panx-1 hemichannels and subsequent release of ATP occurs in the early events of apoptosis, and no opening of Panx-1 hemichannels was observed in the later events of apoptosis (Chekeni et al., 2010). Sandilos et al. determined that the C-terminus functions as a dissociable channel blocker, capable of inhibiting C-terminally truncated Panx-1 hemichannels and relief of C-terminal inhibition followed by cleavage does not happen if the $\mathrm{C}$ terminus is covalently tethered to the channel pore (Sandilos et al., 2012). This evidence suggests a role for Panx-1 hemichannels in the early events of apoptosis.

Divergent from the idea that Panx-1 hemichannels do not form gap junctions Vanden Abeele et al. demonstrated that overexpression of Panx-1 induces formation of $\mathrm{Ca}^{2+}$ permeable gap junction channels between cells allowing cellular $\mathrm{Ca}^{2+}$ diffusion and facilitating intercellular $\mathrm{Ca}^{2+}$ wave propagation (Vanden Abeele et al., 2006). Panx-1 overexpression also increased the $\mathrm{Ca}^{2+}$ permeability of the endoplasmic reticulum (ER) membrane and affected intraluminal ER $\mathrm{Ca}^{2+}$ concentration. Using human prostate cancer epithelial cells (LNCaP) and human embryonic kidney cells (HEK-293) they demonstrated that while overexpression drastically reduced intraluminal $\mathrm{Ca}^{2+}$, endogenous Panx-1 depletion using siRNA increased the content of $\mathrm{Ca}^{2+}$ in the ER. This data suggests that Panx-1 hemichannels are not only found on the plasma membrane but also in the ER membrane, and it participates in $\mathrm{ER} \mathrm{Ca}^{2+}$ leak and intracellular $\mathrm{Ca}^{2+}$ movement. Vanden Abeele et al speculated that the reduced concentration of $\mathrm{Ca}^{2+}$ associated with Panx-1 overexpression could be caused by increase of the BCL-2 family of proteins which plays an important role in the regulation of calcium leak from the ER and is an antiapoptotic protein (Pinton et al., 2000; Vanden Abeele et al., 2002, 2006; Bassik et al., 2004). It may also be due to a deficiency of two pro-apoptotic proteins Bax and Bak (Scorrano et al., 2003; Oakes et al., 2005). This data suggests that Panx-1 could be involved in apoptotic events taking place in endomembranous compartments such as the ER.

\section{PURINERGIC RECEPTORS AND PANX-1 HEMICHANNEL IMPORTANCE IN HIV-1 INFECTION}

The first clinical observations of acquired immune deficiency syndrome (AIDS) were reported in 1981. Since the identification of $\mathrm{HIV}$ as the virus responsible for AIDS the countries affected and the numbers of those infected rose to overwhelming numbers. As of 2011, there are 34 million people worldwide living with HIV according to the World Health Organization. A total of 2.5 million new infections were reported in 2011 with 1.7 million deaths related to AIDS.

The established model for HIV entry into cells is mediated by the binding of HIV glycoprotein (gp) 120 to the cellular CD4 receptor. This interaction induces a conformational change to allow the glycoprotein to bind to the co-receptors CXCR4 and/or CCR5. The interaction of gp120 with these two host receptors creates a stable attachment between the virus and the cell membrane facilitating successful viral entry into the cell. In the past 
two decades studies have documented that binding of HIV or gp120 to the cell rapidly increases the intracellular free calcium concentration (Weissman et al., 1997; Arthos et al., 2000; Liu et al., 2000; Balabanian et al., 2004; Melar et al., 2007). This rapid increase of intracellular free calcium suggests the potential involvement of other membrane receptors or channels in the early stages of HIV infection.

Our laboratory demonstrated that HIV infection of peripheral blood mononuclear cells (PBMCs) and $\mathrm{CD}_{4}^{+} \mathrm{T}$ lymphocytes causes opening of Panx-1 hemichannels in a biphasic manner (Orellana et al., 2013). Binding of the virus to its receptor (CD4) and co-receptors (CXCR4 and/or CCR5) induces opening of Panx-1 hemichannels. Opening of Panx-1 hemichannels in response to the virus resulted in ATP release and subsequent purinergic receptor activation. We also showed that opening of Panx-1 hemichannels was required for HIV entry and replication in $\mathrm{CD}_{4}^{+} \mathrm{T}$ lymphocytes. We propose that opening of Panx-1 hemichannels results in an increase of intracellular calcium and subsequent actin rearrangement, which is a necessary step that allows the virus to fuse with the host cell membrane. The details of these mechanisms are currently under investigation.

Our laboratory recently described a novel role for purinergic receptors in HIV replication in macrophages (Figure 2). We identified that $\mathrm{P} 2 \mathrm{X} 1, \mathrm{P} 2 \mathrm{X} 7$, and $\mathrm{P} 2 \mathrm{Y} 1$ participate in HIV replication.
Demonstrating that $\mathrm{P} 2 \mathrm{X} 1$ is key in controlling viral entry into human macrophages. Although P2X7 and P2Y1 did not inhibit entry, it is highly likely that these receptors participate in later stages of the viral life cycles (Hazleton et al., 2012). We also identified the gp120's binding to primary human macrophages induces the release of ATP which facilitates autocrine activation of purinergic receptors. Panx-1 hemichannels, purinergic receptors and extracellular ATP play a key role in HIV infection and replication of HIV in immune cells by contributing to entry and possibly in other steps of the viral life cycle. In agreement another study using cell lines and PBMCs indicates that extracellular ATP activates P2Y2 receptors resulting in Pyk2 Kinase activation (Seror et al., 2011). It has been reported that Panx1 hemichannels, P2Y2 and Pyk2 are physically recruited to the infection synapse (the contact site between the viral and cellular membrane) in order to facilitate infection (Seror et al., 2011). We propose that this process causes membrane depolarization and assists in membrane-to-membrane fusion allowing viral entry.

\section{POTENTIAL HEMICHANNEL AND PURINERGIC RECEPTOR THERAPIES}

Purinergic receptor, Panx-1 hemichannel, and extracellular ATP, ADP, AMP, and adenosine blockers and their potential use as therapeutic agents are under current investigation. Commercially

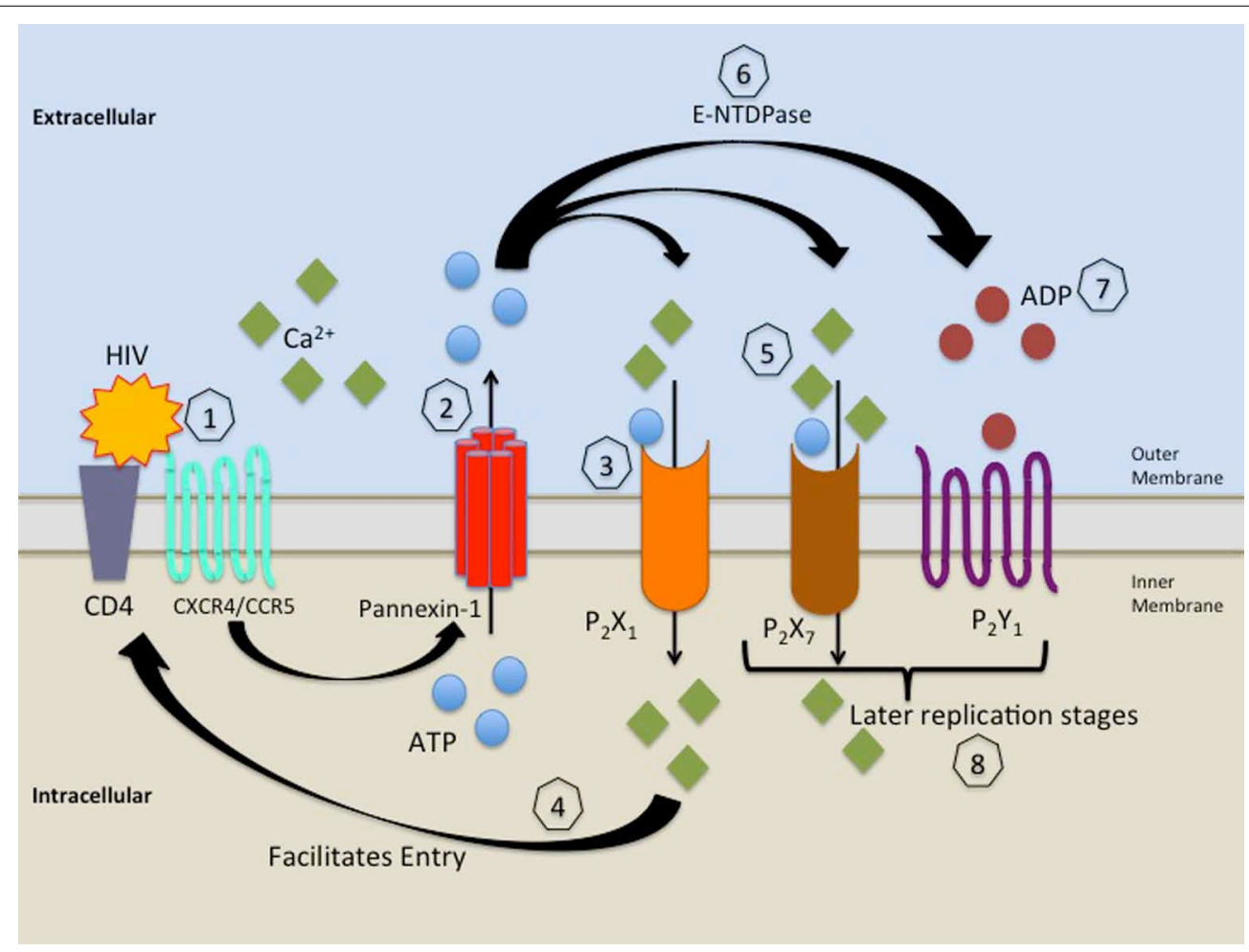

FIGURE 2 | Proposed model for the role of Panx-1 hemichannels and purinergic receptors in HIV infection. HIV's binding to CD4 and CXCR4/CCR5 (1) induces signaling which leads to opening of Panx-1 hemichannels and release of ATP (2). Extracellular ATP released through open Panx-1 hemichannels binds to and activates $\mathrm{P} 2 \mathrm{X} 1$ receptors causing calcium influx (3), which facilitates HIV entry (4). The release of
ATP continues and activates P2X7 and P2Y1 receptors (5), causing further calcium influx inducing downstream signaling, which facilitates later stages of the HIV life cycle (8). Ecto-nucleoside triphosphate diphosphydrolase (E-NTDPase) converts ATP to ADP (6), which activates P2Y1 receptors (7), which increases intracellular calcium, which causes signaling that facilitates later stages of the HIV life cycle (8). 
available pharmaceutical adenosine, such as adenocard and adenoscan, are currently used to treat supraventricular tachycardia, is an example of an ion channel targeted treatment (Delacrétaz, 2006; Jacobson and Gao, 2006). Other clinically used drugs include dipyridamole and methotrexate, which are used to alter the extracellular adenosine concentration as well as signaling. Currently the US Food and Drug Administration (FDA) approved the A2A receptor agonist regadenoson (Lexiscan; Astellas Pharma) for myocardial perfusion imaging in patients with suspected coronary artery disease (Ghimire et al., 2013).

Among purinergic receptor blockers, which are, consumed daily are food dyes such as Brilliant Blue $\mathrm{G}$ (BBG) and Brilliant Blue FCF (BB FCF) which are found in most soft drinks. These dyes are shown to block at least P2X7 receptors, and Panx1 hemichannels respectively (Jiang et al., 2000; Wang et al., 2013). In addition millions of people worldwide consume caffeine, which antagonize adenosine receptors and is used to treat premature apnoea. Actually, nothing is known of the effect that these dyes and caffeine have in physiological and pathological conditions. For example daily ingestion of these compounds in HIV positive individuals could cause the virus to adapt to these blockers changing the course of the disease. As mentioned above these channels/receptors play a role in inflammation and immune response, therefore individuals who consume these dyes in large quantities could also suffer from a suppressed immune response leading to numerous pathologies and susceptibility to pathogens. Further studies are required to investigate the effect that these dyes have among the human population.

The P2Y12 platelet receptor plays an important role in the genesis of platelet aggregation (Power et al., 2012; Tam et al., 2012). Current treatments blocking adenosine diphosphate (ADP) binding to the $\mathrm{P} 2 \mathrm{Y} 12$ receptor, which inhibits platelet aggregation, are commercially available as well as in clinical trials. The first generation thienopyridine drugs which are used for their anti-platelet activity was ticlopidine, which bound irreversibly to P2Y12 platelet receptor (Cattaneo, 2010; Mohelmani and Jackson, 2012). However, its toxicity led to the development of second-generation thienopyridine clopidogrel (Ji and Hou, 2011). Clopidogrel also has its limitations, such as a delay in platelet block because the prodrug requires activation in the liver, and clopidogrel therapy is irreversible which can lead to increase bleeding and transfusion risk in cardiothoracic surgery (Power et al., 2012; Tam et al., 2012). Third generation thienopyridine prasugrel addressed the issue of delayed platelet blocking by being relatively independent of hepatic activation, however, it still remained irreversible and patients were still at risk for increase bleeding (Ferraris et al., 2012). Ticagrelor is an orally administered direct acting platelet blocker, which binds reversibly to the P2Y12receptor. This drug does not require metabolic conversion. It also belongs to a new class of drugs called cyclopyrimidines, which bind, non-competitively to the P2Y12receptor independently of the ADP binding site (van Giezen and Humphries, 2005). Ticagrelor when compared to prasugrel has demonstrated a more promising outcome with fewer side effects.

Numerous clinical trials are on going using various adenosine receptor agonist and antagonist. The expectation are high and could provide treatments for many physiological and pathological conditions such as lipolysis, renal blood flow, immune function, sleep regulation, angiogenesis, inflammatory diseases, ischemiareperfusion, and neurodegenerative disorders (Sun et al., 2001; Huang et al., 2005; Fredholm, 2007; Johansson et al., 2007; Haskó et al., 2008; Rosenberger et al., 2009; Liu et al., 2010; Eltzschig and Carmeliet, 2011; Eltzschig and Eckle, 2011; Lazarus et al., 2011; Grenz et al., 2012). However, developing adenosine receptor targets is challenging because adenosine signaling is widespread. Therefore it is necessary to use ligands, which could be successfully administered to affect the area of interest, while being safe to use in a clinical setting.

Probenecid is a Panx-1 inhibitor, and has been on the market for decades as a treatment for gouty arthritis. High levels of extracellular potassium ion induce inflammasome activation and caspase 1 cleavage in neurons and astrocytes. In addition probenecid has been shown to attenuate the caspase 1 cleavage in cultured neurons induced by extracellular potassium ions (Peng et al., 2009). Recent evidence using a mouse model has shown that administering probenecid prior to and after stroke induced reduced infarct size, decreased cerebral water content, inhibited neuronal death, and reduced inflammation in the brain (Xiong et al., 2014). These results suggest that probenecid could be used as a treatment for stroke. Another Panx-1 inhibitor is carbenoxolone prescribed to treat oesophageal ulceration and inflammation. Probenecid and carbenoxolone could be ideal candidates as a treatment for pathological as well as physiological conditions were the inhibition of Panx-1 hemichannels could be useful. Other possible treatments could involve the use of mimetic peptides, which are designed with sequences found in the two extracellular loops of the Panx protein. These peptides mimic the loop-to-loop interaction between two hemichannels and activate a docking gate keeping the hemichannel closed. The designs of better and more specific blockers are required in the treatment of diseases involving Panx-1 hemichannels, purinergic receptors and ATP/adenosine.

\section{CONCLUSION}

In this review we have discussed the role which purinergic receptors and Panx-1 hemichannels play in the pathogenesis of several human diseases. It is crucial to understand the contribution of these receptors and channels in physiological and pathological conditions, in order to design new and improved therapeutic approaches. The contribution that purinergic receptors and Panx1 hemichannels play in the HIV viral life cycle has only been recently described and unlocking this relationship could hold the key to the development of new preventative therapies and treatments. Purinergic receptor, Panx-1 hemichannel, and extracellular ATP, ADP, AMP, and adenosine are important modulators of many cellular events and hold great potential in understanding and treating many pathological and physiological conditions. The pathologies discussed in this review contribute to a large number of fatalities worldwide. Although much progress has been made in the advancement of treatments for these pathologies, there are still many avenues, which have not been explored. As more information regarding Panx-1 hemichannels and purinergic receptors emerge, the possibility of new therapeutic opportunities for these pathologies emerges as well. 


\section{ACKNOWLEDGMENTS}

We would like to thank the New Jersey Blood Center, the Alfred P. Sloan Foundation Minority fellowship (to Stephani Velasquez) and Mount Sinai NeuroAIDS Disparities Summer Institute, R25 MH080663 (to Stephani Velasquez). This work was supported by the National Institute of Mental Health grant, MH096625, and PHRI funding (to Eliseo A. Eugenin). We thank Megan Velasquez and Omar Santos Cedeño for reading the manuscript. The authors had no financial interest.

\section{REFERENCES}

Abbracchio, M. P., and Burnstock, G. (1998). Purinergic signaling: pathophysiological roles. Jpn. J. Pharmacol. 78, 113-145. doi: 10.1254/jjp.78.113

Adair, T. H. (2005). Growth regulation of the vascular system: an emerging role for adenosine. Am. J. Physiol. Regul. Integr. Comp. Physiol. 289, R283-R296. doi: 10.1152/ajpregu.00840.2004

Antonioli, L., Pacher, P., Vizi, E. S., and Haskó, G. (2013). CD39 and CD73 in immunity and inflammation. Trends Mol. Med. 19, 355-367. doi: 10.1016/j.molmed.2013.03.005

Arthos, J., Rubbert, A., Rabin, R. L., Cicala, C., Machado, E., Wildt, K., et al. (2000). CCR5 signal transduction in macrophages by human immunodeficiency virus and simian immunodeficiency virus envelopes. J. Virol. 74, 6418-6424. doi: 10.1128/JVI.74.14.6418-6424.2000

Ayna, G., Krysko, D. V., Kaczmarek, A., Petrovski, G., and Vandenabeele, P. (2012). ATP release from dying autophagic cells and their phagocytosis are crucial for inflammasome activation in macrophages. PLoS ONE 7:e40069. doi: 10.1371/journal.pone.0040069

Balabanian, K., Harriague, J., Décrion, C., Lagane, B., Shorte, S., Baleux, F., et al. (2004). CXCR4-tropic HIV-1 envelope glycoprotein functions as a viral chemokine in unstimulated primary CD4+ T lymphocytes. J. Immunol. 173, 7150-7160.

Bao, B. A., Lai, C. P., Naus, C. C., and Morgan, J. R. (2012). Pannexin1 drives multicellular aggregate compaction via a signaling cascade that remodels the actin cytoskeleton. J. Biol. Chem. 287, 8407-8416. doi: 10.1074/jbc.M111.306522

Bao, Y., Chen, Y., Ledderose, C., Li, L., and Junger, W. G. (2013). Pannexin 1 channels link chemoattractant receptor signaling to local excitation and global inhibition responses at the front and back of polarized neutrophils. J. Biol. Chem. 288, 22650-22657. doi: 10.1074/jbc.M113.476283

Baranova, A., Ivanov, D., Petrash, N., Pestova, A., Skoblov, M., Kelmanson, I., et al. (2004). The mammalian pannexin family is homologous to the invertebrate innexin gap junction proteins. Genomics 83, 706-716. doi: 10.1016/j.ygeno.2003.09.025

Barbe, M. T., Monyer, H., and Bruzzone, R. (2006). Cell-cell communication beyond connexins: the pannexin channels. Physiology (Bethesda) 21, 103-114. doi: 10.1152/physiol.00048.2005

Bargiotas, P., Krenz, A., Hormuzdi, S. G., Ridder, D. A., Herb, A., Barakat, W., et al. (2011). Pannexins in ischemia-induced neurodegeneration. Proc. Natl. Acad. Sci. U.S.A. 108, 20772-20777. doi: 10.1073/pnas.1018262108

Bassik, M. C., Scorrano, L., Oakes, S. A., Pozzan, T., and Korsmeyer, S. J. (2004). Phosphorylation of BCL-2 regulates ER Ca2+ homeostasis and apoptosis. EMBO J. 23, 1207-1216. doi: 10.1038/sj.emboj.7600104

Berzat, A., and Hall, A. (2010). Cellular responses to extracellular guidance cues. EMBO J. 29, 2734-2745. doi: 10.1038/emboj.2010.170

Boassa, D., Ambrosi, C., Qiu, F., Dahl, G., Gaietta, G., and Sosinsky, G. (2007). Pannexin1 channels contain a glycosylation site that targets the hexamer to the plasma membrane. J. Biol. Chem. 282, 31733-31743. doi: 10.1074/jbc.M702422200

Borsellino, G., Kleinewietfeld, M., Di Mitri, D., Sternjak, A., Diamantini, A., Giometto, R., et al. (2007). Expression of ectonucleotidase CD39 by Foxp3+ Treg cells: hydrolysis of extracellular ATP and immune suppression. Blood 110, 1225-1232. doi: 10.1182/blood-2006-12-064527

Bours, M. J., Swennen, E. L., Di Virgilio, F., Cronstein, B. N., and Dagnelie, P. C. (2006). Adenosine 5'-triphosphate and adenosine as endogenous signaling molecules in immunity and inflammation. Pharmacol. Ther. 112, 358-404. doi: 10.1016/j.pharmthera.2005.04.013

Bruzzone, R., Barbe, M. T., Jakob, N. J., and Monyer, H. (2005). Pharmacological properties of homomeric and heteromeric pannexin hemichannels expressed in Xenopus oocytes. J. Neurochem. 92, 1033-1043. doi: 10.1111/j.14714159.2004.02947.x

Bruzzone, R., and Dermietzel, R. (2006). Structure and function of gap junctions in the developing brain. Cell Tissue Res. 326, 239-248. doi: 10.1007/s00441-0060287-0

Bruzzone, R., Hormuzdi, S. G., Barbe, M. T., Herb, A., and Monyer, H. (2003). Pannexins, a family of gap junction proteins expressed in brain. Proc. Natl. Acad. Sci. U.S.A. 100, 13644-13649. doi: 10.1073/pnas.2233464100

Buchheiser, A., Ebner, A., Burghoff, S., Ding, Z., Romio, M., Viethen, C., et al. (2011). Inactivation of CD73 promotes atherogenesis in apolipoprotein Edeficient mice. Cardiovasc. Res. 92, 338-347. doi: 10.1093/cvr/cvr218

Burnstock, G. (2006). Pathophysiology and therapeutic potential of purinergic signaling. Pharmacol. Rev. 58, 58-86. doi: 10.1124/pr.58.1.5

Burnstock, G. (2012). Purinergic signalling: its unpopular beginning, its acceptance and its exciting future. Bioessays 34, 218-225. doi: 10.1002/bies.201100130

Burnstock, G., and Knight, G. E. (2004). Cellular distribution and functions of p2 receptor subtypes in different systems. Int. Rev. Cytol. 240, 31-304. doi: 10.1016/S0074-7696(04)40002-3

Burnstock, G., and Verkhratsky, A. (2010). Long-term (trophic) purinergic signalling: purinoceptors control cell proliferation, differentiation and death. Cell Death Dis. 1, e9. doi: 10.1038/cddis.2009.11

Carmeliet, P., Dor, Y., Herbert, J. M., Fukumura, D., Brusselmans, K., Dewerchin, M., et al. (1998). Role of HIF-lalpha in hypoxia-mediated apoptosis, cell proliferation and tumour angiogenesis. Nature 394, 485-490. doi: 10.1038/ 28867

Cattaneo, M. (2010). New P2Y12 inhibitors.Circulation 121, 171-179. doi: 10.1161/CIRCULATIONAHA.109.853069

Cavaliere, F., Amadio, S., Dinkel, K., Reymann, K. G., and Volonte, C. (2007). P2 receptor antagonist trinitrophenyl-adenosine-triphosphate protects hippocampus from oxygen and glucose deprivation cell death. J. Pharmacol. Exp. Ther. 323, 70-77. doi: 10.1124/jpet.106.119024

Cavaliere, F., Florenzano, F., Amadio, S., Fusco, F. R., Viscomi, M. T., D’Ambrosi, N., et al. (2003). Up-regulation of $\mathrm{p} 2 \times 2, \mathrm{p} 2 \times 4$ receptor and ischemic cell death: prevention by $\mathrm{p} 2$ antagonists. Neuroscience 120, 85-98. doi: 10.1016/S03064522(03)00228-8

Cavaliere, F., Sancesario, G., Bernardi, G., and Volonté, C. (2002). Extracellular ATP and nerve growth factor intensify hypoglycemia-induced cell death in primary neurons: role of P2 and NGFRp75 receptors. J. Neurochem. 83, 1129-1138. doi: 10.1046/j.1471-4159.2002.01205.x

Chekeni, F. B., Elliott, M. R., Sandilos, J. K., Walk, S. F., Kinchen, J. M., Lazarowski, E. R., et al. (2010). Pannexin 1 channels mediate 'find-me' signal release and membrane permeability during apoptosis. Nature 467, 863-867. doi: 10.1038/nature09413

Chen, Y., Corriden, R., Inoue, Y., Yip, L., Hashiguchi, N., Zinkernagel, A., et al. (2006). ATP release guides neutrophil chemotaxis via P2Y2 and A3 receptors. Science 314, 1792-1795. doi: 10.1126/science.1132559

Chen, Y., Yao, Y., Sumi, Y., Li, A., To, U. K., Elkhal, A., et al. (2010). Purinergic signaling: a fundamental mechanism in neutrophil activation. Sci. Signal. 3, ra45. doi: 10.1126/scisignal.2000549

Cotrina, M. L., Lin, J. H. C., and Nedergaard, M. (1998). Cytoskeletal assembly and ATP release regulate astrocytic calcium signaling. J. Neurosci. 18, 8794-8804.

Cruz, C. M., Rinna, A., Forman, H. J., Ventura, A. L., Persechini, P. M., and Ojcius, D. M. (2007). ATP activates a reactive oxygen species-dependent oxidative stress response and secretion of proinflammatory cytokines in macrophages. J. Biol. Chem. 282, 2871-2879. doi: 10.1074/jbc.M608083200

Davalos, D., Grutzendler, J., Yang, G., Kim, J. V., Zuo, Y., Jung, S., et al. (2005). ATP mediates rapid microglial response to local brain injury in vivo. Nat. Neurosci. 8, 752-758. doi: 10.1038/nn1472

Davis, B. K., Wen, H., and Ting, J. P. (2011). The inflammasome NLRs in immunity, inflammation, and associated diseases. Annu. Rev. Immunol. 29, 707-735. doi 10.1146/annurev-immunol-031210-101405

Deaglio, S., Dwyer, K. M., Gao, W., Friedman, D., Usheva, A., Erat, A., et al. (2007). Adenosine generation catalyzed by CD39 and CD73 expressed on regulatory T cells mediates immune suppression J. Exp. Med. 204, 1257-1265. doi: 10.1084/jem.20062512

Delacrétaz, E. (2006). Clinical practice. Supraventricular tachycardia. N. Engl. J. Med. 354, 1039-1051. doi: 10.1056/NEJMcp051145

Diezmos, E. F., Sandow, S. L., Markus, I., Shevy Perera, D., Lubowski, D. Z., King, D. W., et al. (2013). Expression and localization of pannexin-1 hemichannels in 
human colon in health and disease. J. Neurogastroenterol. Motil. 25, e395-e405. doi: $10.1111 /$ nmo. 12130

Dirnagl, U., Iadecola, C., and Moskowitz, M. A. (1999). Pathobiology of ischaemic stroke: an integrated view. Trends Neurosci. 22, 391-397. doi: 10.1016/S01662236(99)01401-0

Di Virgilio, F. (2007). Liaisons dangereuses: P2X(7). and the inflammasome. Trends Pharmacol. Sci. 28, 465-472. doi: 10.1016/j.tips.2007.07.002

Di Virgilio, F., Ceruti, S., Bramanti, P., and Abbracchio, M. P. (2009). Purinergic signalling in inflammation of the central nervous system. Trends Neurosci. 32, 79-87. doi: 10.1016/j.tins.2008.11.003

Domercq, M., Perez-Samartin, A., Aparicio, D., Alberdi, E., Pampliega, O., and Matute, C. (2010). P2X7 receptors mediate ischemic damage to oligodendrocytes. Glia 58, 730-740. doi: 10.1002/glia.20958

Dwyer, K. M., Hanidziar, D., Putheti, P., Hill, P. A., Pommey, S., McRae, J. L., et al. (2010). Expression of CD39 by human peripheral blood CD4+ CD25+ T cells denotes a regulatory memory phenotype. Am. J. Transplant. 10, 2410-2420. doi: 10.1111/j.1600-6143.2010.03291.x

Elliott, M. R., Chekeni, F. B., Trampont, P. C., Lazarowski, E. R., Kadl, A., Walk, S. F., et al. (2009). Nucleotides released by apoptotic cells act as a find-me signal to promote phagocytic clearance. Nature 461, 282-286. doi: 10.1038/nature08296

Eltzschig, H. K., and Carmeliet, P. (2011). Hypoxia and Inflammation. N. Engl. J. Med. 364, 656-665. doi: 10.1056/NEJMra0910283

Eltzschig, H. K., and Eckle, T. (2011). Ischemia and reperfusion-from mechanism to translation. Nat. Med. 17, 1391-1401. doi: 10.1038/nm.2507

Erlinge, D., and Burnstock, G. (2008). P2 receptors in cardiovascular regulation and disease. Purinergic Signal. 4, 1-20. doi: 10.1007/s11302-007-9078-7

Ferrari, D., Pizzirani, C., Adinolfi, E., Lemoli, R. M., Curti, A., Idzko, M., et al. (2006). The P2X7 receptor: a key player in IL-1 processing and release. J. Immunol. 176, 3877-3883.

Ferrara, N., Gerber, H. P., and LeCouter, J. (2003). The biology of VEGF and its receptors. Nat. Med. 9, 669-676. doi: 10.1038/nm0603-669

Ferraris, V. A., Saha, S. P., Oestreich, J. H., Song, H. K., Rosengart, T., Reece, T. B., et al. (2012). Society of Thoracic Surgeons 2012 update to the society of thoracic surgeons guideline on use of antiplatelet drugs in patients having cardiac and noncardiac operations. Ann. Thorac. Surg. 94, 1761-1781. doi: 10.1016/j.athoracsur.2012.07.086

Fredholm, B. B. (2007). Adenosine, an endogenous distress signal, modulates tissue damage and repair. Cell Death Differ. 14, 1315-1323. doi: 10.1038/sj.cdd. 4402132

Fredholm, B. B., Abbracchio, M. P., Burnstock, G., Daly, J. W., Harden, K., Jacobson, K. A., et al. (1994). Nomenclature and classification of purinoceptors. Pharmacol. Rev. 46, 143-156.

Gessi, S., Fogli, E., Sacchetto, V., Merighi, S., Varani, K., Preti, D., et al. (2010). Adenosine modulates HIF-1 \{alpha\}, VEGF, IL-8, and foam cell formation in a human model of hypoxic foam cells. Arterioscler. Thromb. Vasc. Biol. 30, 90-97. doi: 10.1161/ATVBAHA.109.194902

Ghimire, G., Hage, F. G., Heo, J., and Iskandrian, A. E. (2013). Regadenoson: a focused update. J. Nucl. Cardiol. 20, 284-288. doi: 10.1007/s12350-012-9661-3

Ghiringhelli, F., Apetoh, L., Tesniere, A., Aymeric, L., Ma, Y., Ortiz, C., et al. (2009). Activation of the NLRP3 inflammasome in dendritic cells induces IL-1betadependent adaptive immunity against tumors. Nat. Med. 15, 1170-1178. doi: $10.1038 / \mathrm{nm} .2028$

Glass, C. K., and Witztum, J. L. (2001). Atherosclerosis: The Road Ahead. Cell 104, 503-516. doi: 10.1016/S0092-8674(01)00238-0

Gorski, D. H., and Walsh, K. (1995). Mitogen-responsive nuclear factors that mediate growth control signals in vascular myocytes. Cardiovasc. Res. 30, 585-592. doi: 10.1016/S0008-6363(96)88508-7

Grenz, A., Bauerle, J. D., Dalton, J. H., Ridyard, D., Badulak, A., Tak, E., et al. (2012). Equilibrative nucleoside transporter 1 (ENT1) regulates postischemic blood flow during acute kidney injury in mice. J. Clin. Invest. 122, 693-710. doi: 10.1172/JCI60214

Gulbransen, B. D., Bashashati, M., Hirota, S. A., Gui, X., Roberts, J. A., MacDonald, J. A., et al. (2012). Activation of neuronal P2X7 receptor-pannexin-1 mediates death of enteric neurons during colitis. Nat. Med. 18, 600-604. doi: 10.1038/nm.2679

Hansson, G. K., and Hermansson, A. (2011). The immune system in atherosclerosis. Nat. Immunol. 12, 204-212. doi: 10.1038/ni.2001

Harris, A. L. (2007). Connexin channel permeability to cytoplasmic molecules. Prog. Biophys. Mol. Biol. 94, 120-143. doi: 10.1016/j.pbiomolbio.2007.03.011
Haskó, G., Linden, J., Cronstein, B., and Pacher, P. (2008). Adenosine receptors: therapeutic aspects for inflammatory and immune diseases. Nat. Rev. Drug Discov. 7, 759-770. doi: 10.1038/nrd2638

Hazleton, J. E., Berman, J. W., and Eugenin, E. A. (2012). Purinergic receptors are required for HIV-1 infection of primary human macrophages. J. Immunol. 188, 4488-4495. doi: 10.4049/jimmunol.1102482

Hou, M., Moller, S., Edvinsson, L., and Erlinge, D. (2000). Cytokines induce upregulation of vascular P2Y2 receptors and increased mitogenic responses to UTP and ATP. Arterioscler. Thromb. Vasc. Biol. 20, 2064-2069. doi: 10.1161/01.ATV.20.9.2064

Huang, C., Han, X., Li, X., Lam, E., Peng, W., Lou, N., et al. (2012). Critical role of connexin 43 in secondary expansion of traumatic spinal cord injury. J. Neurosci. 32, 3333-3338. doi: 10.1523/JNEUROSCI.1216-11.2012

Huang, Z. L., Qu, W. M., Eguchi, N., Chen, J. F., Schwarzschild, M. A., Fredholm, B. B., et al. (2005). Adenosine A2A, but not A1, receptors mediate the arousal effect of caffeine. Nat. Neurosci. 8, 858-859. doi: 10.1038/nn1491

Hung, S. C., Choi, C. H., Said-Sadier, N., Johnson, L., Atanasova, K. R., Sellami, H., et al. (2013). P2X4 assembles with P2X7 and pannexin-1 in gingival epithelial cells and modulates ATP-induced reactive oxygen species production and inflammasome activation. PLoS ONE 8:e70210. doi: 10.1371/journal.pone. 0070210

Idzko, M., Hammad, H., van Nimwegen, M., Kool, M., Willart, M. A., Muskens, F., et al. (2007). Extracellu8lar ATP triggers and maintains asthmatic airway inflammation by activating dendritic cells. Nat. Med. 13, 913-919. doi: $10.1038 / \mathrm{nm} 1617$

Iglesias, R., Dahl, G., Qiu, F., Spray, D. C., and Scemes, E. (2009). Pannexin 1: the molecular substrate of astrocyte "hemichannels". J. Neurosci. 29, 7092-7097. doi: 10.1523/JNEUROSCI.6062-08.2009

Jacobson, K. A., and Gao, Z. G. (2006). Adenosine receptors as therapeutic targets. Nat. Rev. Drug Discov. 5, 247-264. doi: 10.1038/nrd1983

James, G., and Butt, A. M. (2001). P2X and P2Y purinoreceptors mediate ATPevoked calcium signalling in optic nerve glia in situ. Cell Calcium 30, 251-259. doi: 10.1054/ceca.2001.0232

Ji, X., and Hou, M. (2011). Novel agents for antiplatelet therapy. J. Hematol. Oncol. 4, 4-44. doi: 10.1186/1756-8722-4-44

Jiang, G., Li, T., Qiu, Y., Rui, Y., Chen, W., and Lou, Y. (2007). RNA interference for HIF-1alpha inhibits foam cells formation in vitro. Eur. J. Pharmacol. 562, 183-190. doi: 10.1016/j.ejphar.2007.01.066

Jiang, L. H., Mackenzie, A. B., North, R. A., and Surprenant, A. (2000). Brilliant Blue G selectively blocks ATP-gated rat P2X7 receptors. Mol. Pharmacol. 58, 82-88. doi: 10.1124/mol.58.1.82

Johansson, S. M., Yang, J. N., Lindgren, E., and Fredholm, B. B. (2007). Eliminating the antilipolytic adenosine A1 receptor does not lead to compensatory changes in the antilipolytic actions of PGE2 and nicotinic acid. Acta Physiol. 190, 87-96. doi: 10.1111/j.1365-201X.2007.01692.x

Jonzon, B., Nilsson, J., and Fredholm, B. B. (1985). Adenosine receptor-mediated changes in cyclic AMP production and DNA synthesis in cultured arterial smooth muscle cells. J. Cell. Physiol. 124, 451-456. doi: 10.1002/jcp.1041240314

Junger, W. G. (2011). Immune cell regulation by autocrine purinergic signalling. Nat. Rev. Immunol. 11, 201-212. doi: 10.1038/nri2938

Kanneganti, T. D., Body-Malapel, M., Amer, A., Park, J. H., Whitfield, J., Franchi, L., et al. (2006). Critical role for Cryopyrin/Nalp3 in activation of caspase- 1 in response to viral infection and double-stranded RNA. J. Biol. Chem. 281, 36560-36568. doi: 10.1074/jbc.M607594200

Katsura, K., Kristian, T., and Siesjo, B. K. (1994). Energy metabolism, ion homeostasis, and cell damage in the brain. Biochem. Soc. Trans. 22, 991-996.

Kirischuk, S., Scherer, J., Kettenmann, H., and Verkhratsky, A. (1995). Activa- tion of $\mathrm{P} 2$-purinoreceptors triggered $\mathrm{Ca} 21$ release from InsP3-sensi- tive internal stores in mammalian oligodendrocytes. J. Physiol. 483, 41-57.

Koupenova, M., Johnston-Cox, H., and Ravid, K. (2012b). Regulation of atherosclerosis and associated risk factors by adenosine and adenosine receptors. Curr. Atheroscler. Rep. 14, 460-468. doi: 10.1007/s11883-0120263-y

Koupenova, M., Johnston-Cox, H., Vezeridis, A., Gavras, H., Yang, D., Zannis, V., et al. (2012a). A2b adenosine receptor regulates hyperlipidemia and atherosclerosis. Circulation 125, 354-363. doi: 10.1161/CIRCULATIONAHA.111.057596

Kourembanas, S., Morita, T., Christou, H., Liu, Y., Koike, H., Brodsky, D. et al. (1998). Hypoxic responses of vascular cells. Chest 114, 25S-28S. doi: 10.1378/chest.114.1_Supplement.25S-a 
Lacombe, C., and Mayeux, P. (1998). Biology of erythropoietin. Haematologica 83, $724-732$.

Lammer, A., Gunther, A., Beck, A., Krugel, U., Kittner, H., Schneider, D., et al. (2006). Neuroprotective effects of the P2 receptor antagonist PPADS on focal cerebral ischaemia-induced injury in rats. Eur. J. Neurosci. 23, 2824-2828. doi: 10.1111/j.1460-9568.2006.04825.x

Lammer, A. B., Beck, A., Grummich, B., Forschler, A., Krugel, T., Kahn, T., et al. (2011). The P2 receptor antagonist PPADS supports recovery from experimental stroke in vivo. PLoS ONE 6:e19983. doi: 10.1371/journal.pone.0019983

Lazarus, M., Shen, H. Y., Cherasse, Y., Qu, W. M., Huang, Z. L., Bass, C. E., et al. (2011). Arousal effect of caffeine depends on adenosine A2A receptors in the shell of the nucleus accumbens. J. Neurosci. 31, 10067-10075. doi: 10.1523/JNEUROSCI.6730-10.2011

Lich, J. D., Arthur, J. C., and Ting, J. P. (2006). Cryopyrin: in from the cold. Immunity 24, 241-243. doi: 10.1016/j.immuni.2006.03.004

Liu, Q. H., Williams, D. A., McManus, C., Baribaud, F., Doms, R. W., Schols, D., et al. (2000). HIV-1 gp120 and chemokines activate ion channels in primary macrophages through CCR5 and CXCR4 stimulation. Proc. Natl. Acad. Sci. U.S.A. 97, 4832-4837. doi: 10.1073/pnas.090521697

Liu, X. L., Zhou, R., Pan, Q. Q., Jia, X. L., Gao, W. N., Wu, J., et al. (2010). Genetic inactivation of the adenosine A2A receptor attenuates pathologic but not developmental angiogenesis in the mouse retina. Invest. Ophthalmol. Vis. Sci. 51, 6625-6632. doi: 10.1167/iovs.09-4900

Liu, Y., Cox, S. R., Morita, T., and Kourembanas, S. (1995). Hypoxia regulates vascular endothelial growth factor gene expression in endothelial cells. Identification of a $5^{\prime}$ enhancer. Circ. Res. 77, 638-643. doi: 10.1161/01.RES.77.3.638

Locovei, S., Scemes, E., Qiu, F., Spray, D. C., and Dahl, G. (2007). Pannexin1 is part of the pore forming unit of the $\mathrm{P} 2 \mathrm{X}(7)$ receptor death complex. FEBS Lett. 581, 483-488. doi: 10.1016/j.febslet.2006.12.056

Lommatzsch, M., Cicko, S., Muller, T., Lucattelli, M., Bratke, K., Stoll, P., et al. (2010). Extracellular adenosine triphosphate and chronic obstructive pulmonary disease. Am. J. Respir. Crit. Care Med. 181, 928-934. doi: 10.1164/rccm.200910-1506OC

MacVicar, B. A., and Thompson, R. J. (2010). Non-junction functions of pannexin1 channels. Trends Neurosci. 33, 93-102. doi: 10.1016/j.tins.2009.11.007

Madry, C., Haglerod, C., and Attwell, D. (2010). The role of pannexin hemichannels in the anoxic depolarization of hippocampal pyramidal cells. Brain 133, 3755-3763., doi: 10.1093/brain/awq284

Mandapathil, M., Hilldorfer, B., Szczepanski, M. J., Czystowska, M., Szajnik, M., Ren, J., et al. (2010). Generation and accumulation of immunosuppressive adenosine by human $\mathrm{CD} 4+\mathrm{CD} 25$ highFOXP3 + regulatory T cells. J. Biol. Chem. 285, 7176-7186. doi: 10.1074/jbc.M109.047423

Mandapathil, M., Lang, S., Gorelik, E., and Whiteside, T. L. (2009). Isolation of functional human regulatory $\mathrm{T}$ cells (Treg) from the peripheral blood based on the CD39 expression. J. Immunol. Methods. 346, 55-63. doi: 10.1016/j.jim.2009.05.004

Mariathasan, S., Weiss, D. S., Newton, K., McBride, J., O’Rourke, K., Roose-Girma, M., et al. (2006). Cryopyrin activates the inflammasome in response to toxins and ATP. Nature 440, 228-232. doi: 10.1038/nature04515

Martin, R. L., Lloyd, H. G., and Cowan, A. I. (1994). The early events of oxygen and glucose deprivation: setting the scene for neuronal death? Trends Neurosci. 17, 251-257. doi: 10.1016/0166-2236(94)90008-6

Mawe, G. M., Strong, D. S., and Sharkey, K. A. (2009). Plasticity of enteric nerve functions in the inflamed and postinflamed gut. Neurogastroenterol. Motil. 21, 481-491. doi: 10.1111/j.1365-2982.2009.01291.x

Melar, M., Ott, D. E., and Hope, T. J. (2007). Physiological levels of virionassociated human immunodeficiency virus type 1 envelope induce coreceptordependent calcium flux. J. Virol. 81, 1773-1785. doi: 10.1128/JVI.01316-06

Meylan, E., Tschopp, J., and Karin, M. (2006). Intracellular pattern recognition receptors in the host response. Nature 442, 39-44. doi: 10.1038/nature04946

Mohelmani, F., and Jackson, D. E. (2012). P2Y(12) receptor: Platelet thrombus formation and medical interventions. Int. J. Hematol. 96, 572-587. doi: $10.1007 /$ s12185-012-1188-5

Moore, K. J., and Tabas, I. (2011). Macrophages in the pathogenesis of atherosclerosis. Cell 145, 341-355. doi: 10.1016/j.cell.2011.04.005

Nimmerjahn, A., Kirchhoff, F., and Helmchen, F. (2005). Resting microglial cells are highly dynamic surveillants of brain parenchyma in vivo. Science 308, 1314-1318. doi: 10.1126/science.1110647
Oakes, S. A., Scorrano, L., Opferman, J. T., Bassik, M. C., Nishino, M., Pozzan, T., et al. (2005). Proapoptotic BAX and BAK regulate the type 1 inositol trisphosphate receptor and calcium leak from the endoplasmic reticulum. Proc. Natl. Acad. Sci. U.S.A. 102, 105-110. doi: 10.1073/pnas.0408352102

Ohta, A., Kini, R., Ohta, A., Subramanian, M., Madasu, M., and Sitkovsky, M. (2012). The development and immunosuppressive functions of CD4+ CD25+ FoxP3+ regulatory $\mathrm{T}$ cells are under influence of the adenosine-A2A adenosine receptor pathway. Front. Immunol. 3:190. doi: 10.3389/fimmu.2012.00190

Orellana, J. A., Froger, N., Ezan, P., Jiang, J. X., Bennett, M. V., Naus, C. C., et al. (2011). ATP and glutamate released via astroglial connexin 43 hemichannels mediate neuronal death through activation of pannexin 1 hemichannels. J. Neurochem. 118, 826-840. doi: 10.1111/j.1471-4159.2011.07210.x

Orellana, J. A., Velasquez, S., Williams, D. W., Saez, J. C., Berman, J. W., and Eugenin, E. A. (2013). Pannexinl hemichannels are critical for HIV infection of human primary CD4+ T lymphocytes. J. Leukoc. Biol. 94, 399-407. doi: 10.1189/jlb.0512249

Pelegrin, P. (2008). Targeting interleukin-1 signaling in chronic inflammation: focus on P2X(7) receptor and Pannexin-1. Drug News Perspect. 21, 424-433.

Pelegrin, P., and Surprenant, A. (2006). Pannexin-1 mediates large pore formation and interleukin- $1 \mathrm{~b}$ release by the ATP-gated $\mathrm{P} 2 \mathrm{X} 7$ receptor. EMBO J. 25, 5071-5082. doi: 10.1038/sj.emboj.7601378

Peng, W., Cotrina, M. L., Han, X., Yu, H., Bekar, L., Blum, L., et al. (2009). Systemic administration of an antagonist of the ATP-sensitive receptor P2X7 improves recovery after spinal cord injury. Proc. Natl. Acad. Sci. U.S.A. 106, 12489-12493. doi: 10.1073/pnas.0902531106

Penuela, S., Bhalla, R., Gong, X. Q., Cowan, K. N., Celetti, S. J., Cowan, B. J., et al. (2007). Pannexin 1 and pannexin 3 are glycoproteins that exhibit many distinct characteristics from the connexin family of gap junction proteins. J. Cell Sci. 120, 3772-3783. doi: 10.1242/jcs.009514

Peters, M. A., Teramoto, T., White, J. Q., Iwasaki, K., and Jorgensen, E. M. (2007). A calcium wave mediated by gap junctions coordinates a rhythmic behavior in C. elegans. Curr. Biol. 17, 1601-1608. doi: 10.1016/j.cub.2007.08.031

Pinheiro, A. R., Paramos-de-Carvalho, D., Certal, M., Costa, M. A., Costa, C., Magalhães-Cardoso, M. T., et al. (2013). Histamine induces ATP release from human subcutaneous fibroblasts, via pannexin-1 hemichannels, leading to Ca2+ mobilization and cell proliferation. J. Biol. Chem. 288, 27571-27583. doi: 10.1074/jbc.M113.460865

Pinton, P. D., Ferrari, P., Magalhaes, K., Schulze-Osthoff, F., Di Virgilio, T., and Pozzan, R., Rizzuto. (2000). Reduced loading of intracellular $\mathrm{Ca}(2+)$ stores and downregulation of capacitative $\mathrm{Ca}(2+)$ influx in $\mathrm{Bcl}$-2-overexpressing cells. J. Cell Biol. 148, 857-862. doi: 10.1083/jcb.148.5.857

Power, R. F., Hynes, B. G., Moran, D., Yagoub, H., Kiernan, G., Ruggiero, N. J., et al. (2012). Modern antiplatelet agents in coronary artery disease. Expert Rev. Cardiovasc. Ther. 10, 1261-1272. doi: 10.1586/erc.12.127

Prochnow, N., Abdulazim, A., Kurtenbach, S., Wildförster, V., Dvoriantchikova, G., Hanske, J., et al. (2012). Pannexin1 stabilizes synaptic plasticity and is needed for learning. PLoS ONE 7:e51767. doi: 10.1371/journal.pone.0051767

Qiu, F., and Dahl, G. (2009). A permeant regulating its permeation pore: inhibition of pannexin 1 channels by ATP. Am. J. Physiol. Cell Physiol. 296, C250-C255. doi: 10.1152/ajpcell.00433.2008

Qu, Y., Misaghi, S., Newton, K., Gilmour, L. L., Louie, S., Cupp, J. E., et al. (2011). Pannexin-1 is required for ATP release during apoptosis but not for inflammasome activation. J. Immunol. 186, 6553-6561. doi: 10.4049/jimmunol.1100478

Ralevic, V., and Burnstock, G. (1998). Receptors for purines and pyrimidines. Pharmacol. Rev. 50, 413-492.

Ray, A., Zoidl, G., Wahle, P., and Dermietzel, R. (2006). Pannexin expression in the cerebellum. Cerebellum 5, 189-192. doi: 10.1080/14734220500530082

Reiss, A. B., and Glass, A. D. (2006). Atherosclerosis: immune and inflammatory aspects. J. of Invest. Med. 54, 123-131. doi: 10.2310/6650.2006.05051

Riteau, N., Gasse, P., Fauconnier, L., Gombault, A., Couegnat, M., Fick, L., et al. (2010). Extracellular ATP is a danger signal activating P2X7 receptor in lung inflammation and fibrosis. Am. J. Respir. Crit. Care Med. 182, 774-783. doi: 10.1164/rccm.201003-0359OC

Romio, M., Reinbeck, B., Bongardt, S., Hüls, S., Burghoff, S., and Schrader, J. (2011). Extracellular purine metabolism and signaling of CD73-derived adenosine in murine Treg and Teff cells. Am. J. Physiol. Cell Physiol. 301, C530-C539. doi: 10.1152/ajpcell.00385.2010

Rose, F., Grimminger, F., Appel, J., Heller, M., Pies, V., Weissmann, N., et al. (2002). Hypoxic pulmonary artery fibroblasts trigger proliferation of vascular 
smooth muscle cells: role of hypoxia-inducible transcription factors. FASEB J. 16, 1660-1661. doi: 10.1096/fj.02-0420fje

Rosenberger, P., Schwab, J. M., Mirakaj, V., Masekowsky, E., Mager, A., MoroteGarcia, J. C., et al. (2009). Hypoxia-inducible factor-dependent induction of netrin-1 dampens inflammation caused by hypoxia. Nat. Immunol. 10, 195-202. doi: $10.1038 /$ ni. 1683

Said-Sadier, N., and Ojcius, D. M. (2012). Alarmins, inflammasomes and immunity. Biomed. J. 35, 437-449. doi: 10.4103/2319-4170.104408

Sandilos, J. K., Chiu, Y. H., Chekeni, F. B., Armstrong, A. J., Walk, S. F., Ravichandran, K. S., et al. (2012). Pannexin 1, an ATP release channel, is activated by caspase cleavage of its pore-associated $\mathrm{C}$ terminal autoinhibitory region. J. Biol. Chem. 287, 11303-11311. doi: 10.1074/jbc.M111.323378

Scemes, E., Spray, D. C., and Meda, P. (2009). Connexins, pannexins, innexins: novel roles of "hemi-channels". Pflugers Arch. 457, 1207-1226. doi 10.1007/s00424-008-0591-5

Schenk, U., Westendorf, A. M., Radaelli, E., Casati, A., Ferro, M., Fumagalli, M. et al. (2008). Purinergic control of T cell activation by ATP released through pannexin-1 hemichannels. Sci. Signal. 1, ra6. doi: 10.1126/scisignal.1160583

Schroder, K., and Tschopp, J. (2010). The inflammasomes. Cell 140, 821-832. doi: 10.1016/j.cell.2010.01.040

Schuler, P. J., Harasymczuk, M., Schilling, B., Lang, S., and Whiteside, T. L. (2011). Separation of human CD4+CD39+ T cells by magnetic beads reveals two phenotypically and functionally different subsets. J. Immunol. Methods 369, 59-68. doi: 10.1016/j.jim.2011.04.004

Scorrano, L., Oakes, S. A., Opferman, J. T., Cheng, E. H., Sorcinelli, M. D., et al. (2003). BAX and BAK regulation of endoplasmic reticulum $\mathrm{Ca} 2+$ : a control point for apoptosis. Science 300, 135-139. doi: 10.1126/science.1081208

Semenza, G. L., Roth, P. H., Fang, H. M., and Wang, G. L. (1994). Transcriptional regulation of genes encoding glycolytic enzymes by hypoxia-inducible factor 1 . J. Biol. Chem. 269, 23757-23763.

Seror, C., Melki, M. T., Subra, F., Raza, S. Q., Bras, M., Saidi, H., et al. (2011). Extracellular ATP acts on P2Y2 purinergic receptors to facilitate HIV-1 infection. J. Exp. Med. 208, 1823-1834. doi: 10.1084/jem.20101805

Shatrov, V. A., Sumbayev, V. V., Zhou, J., and Brune, B. (2003). Oxidized lowdensity lipoprotein (oxLDL) triggers hypoxia-inducible factor-1alpha (HIFlalpha) accumulation via redox-dependent mechanisms. Blood 101, 4847-4849. doi: 10.1182/blood-2002-09-2711

Stary, H. C., Chandler, A. B., Glagov, S., Guyton, J. R., Insull, W., Rosenfeld, M. E., et al. (1994). A definition of initial, fatty streak, and intermediate lesions of atherosclerosis. A report from the Committee on Vascular Lesions of the Council on Arteriosclerosis, American Heart Association. Circulation 89, 2462-2478. doi: 10.1161/01.CIR.89.5.2462

Suadicani, S. O., Brosnan, C. F., and Scemes, E. (2006). P2X7 receptors mediate ATP release and amplification of astrocytic intercellular Ca2+ signaling. J. Neurosci. 26, 1378-1385. doi: 10.1523/JNEUROSCI.3902-05.2006

Sun, D., Samuelson, L. C., Yang, T., Huang, Y., Paliege, A., Saunders, T., et al. (2001). Mediation of tubuloglomerular feedback by adenosine: evidence from mice lacking adenosine 1 receptors. Proc. Natl. Acad. Sci. U.S.A. 98, 9983-9988. doi: $10.1073 /$ pnas. 171317998

Sutterwala, F. S., Ogura, Y., Szczepanik, M., Lara-Tejero, M., Lichtenberger, G. S., Grant, E. P., et al. (2006). Critical role for NALP3/CIAS1/Cryopyrin in innate and adaptive immunity through its regulation of caspase-1. Immunity 24, 317-327. doi: 10.1016/j.immuni.2006.02.004

Tam, G. M., Lam, Y. Y., and Yan, B. P. (2012). Novel platelet ADP P2Y12 inhibitors in the treatment of acute coronary syndrome. Cardiovasc. Ther. 30, 167-173. doi: 10.1111/j.1755-5922.2011.00262.x

Thompson, R. J., Jackson, M. F., Olah, M. E., Rungta, R. L., Hines, D. J., Beazely, M. A., et al. (2008). Activation of pannexin-1 hemichannels augments aberrant bursting in the hippocampus. Science 322, 1555-1559. doi: $10.1126 /$ science. 1165209
Thompson, R. J., Zhou, N., and MacVicar, B. A. (2006). Ischemia opens neuronal gap junction hemichannels. Science 312, 924-927. doi: 10.1126/science.11 26241

Vanden Abeele, F., Bidaux, G., Gordienko, D., Beck, B., Panchin, Y. V., Baranova, A. V., et al. (2006). Functional implications of calcium permeability of the channel formed by pannexin 1. J. Cell Biol. 174, 535-546. doi: 10.1083/jcb.2006 01115

Vanden Abeele, F. R., Skryma, Y., Shuba, F., Van Coppenolle, C., Slomianny, M., Roudbaraki, B., et al. (2002). Bcl-2-dependent modulation of $\mathrm{Ca}(2+)$ homeostasis and store-operated channels in prostate cancer cells. Cancer Cell 1, 169-179. doi: 10.1016/S1535-6108(02)00034-X

van Giezen, J. J., and Humphries, R. G. (2005). Preclinical and clinical studies with selective reversible direct P2Y12 inhibitors. Semin. Thromb. Hemost. 31, 195-204. doi: 10.1055/s-2005-869525

Wang, G. L., and Semenza, G. L. (1995). Purification and characterization of hypoxia- inducible factor 1. J. Biol. Chem. 270, 1230-1237. doi: 10.1074/jbc.270.3.1230

Wang, J., Jackson, D. G., and Dahl, G. (2013). The food dye FD\&C Blue No., 1 is a selective inhibitor of the ATP release channel Panx1. J. Gen. Physiol. 141, 649-656. doi: 10.1085/jgp.201310966

Watson, M. L., Grix, S. P., Jordan, N. J., Place, G. A., Dodd, S., Leithead, J., et al. (1998). Interleukin 8 and monocyte chemoattractant protein 1 production by cultured human airway smooth muscle cells. Cytokine 10, 346-352. doi: 10.1006/cyto.1997.0350

Weilinger, N. L., Tang, P. L., and Thompson, R. J. (2012). Anoxia-induced NMDA receptor activation opens pannexin channels via Src family kinases. J. Neurosci. 32, 12579-12588. doi: 10.1523/JNEUROSCI.1267-12.2012

Weissman, D., Rabin, R. L., Arthos, J., Rubbert, A., Dybul, M., Swofford, R., et al. (1997). Macrophage-tropic HIV and SIV envelope proteins induce a signal through the CCR5 chemokine receptor. Nature 389, 981-985. doi: $10.1038 / 40173$

Woehrle, T., Yip, L., Elkhal, A., Sumi, Y., Chen, Y., Yao, Y., et al. (2010). Pannexin1 hemichannel-mediated ATP release together with P2X1 and P2X4 receptors regulate T-cell activation at the immune synapse. Blood 116, 3475-3484. doi: 10.1182/blood-2010-04-277707

Xiong, X. X., Gu, L. J., Shen, J., Kang, X. H., Zheng, Y. Y., Yue, S. B., et al. (2014). Probenecid protects against transient focal cerebral ischemic injury by inhibiting HMGB1 release and attenuating AQP4 expression in mice. Neurochem. Res. 39, 216-224. doi: 10.1007/s11064-013-1212-Z

Yegutkin, G. G. (2008). Nucleotide- and nucleoside-converting ectoenzymes: Important modulators of purinergic signalling cascade. Biochim. Biophys. Acta 1783, 673-694. doi: 10.1016/j.bbamcr.2008.01.024

Conflict of Interest Statement: The authors declare that the research was conducted in the absence of any commercial or financial relationships that could be construed as a potential conflict of interest.

Received: 17 December 2013; paper pending published: 09 January 2014; accepted: 24 February 2014; published online: 14 March 2014.

Citation: Velasquez S and Eugenin EA (2014) Role of Pannexin-1 hemichannels and purinergic receptors in the pathogenesis of human diseases. Front. Physiol. 5:96. doi: 10.3389/fphys.2014.00096

This article was submitted to Membrane Physiology and Membrane Biophysics, a section of the journal Frontiers in Physiology.

Copyright (C) 2014 Velasquez and Eugenin. This is an open-access article distributed under the terms of the Creative Commons Attribution License (CC BY). The use, distribution or reproduction in other forums is permitted, provided the original author(s) or licensor are credited and that the original publication in this journal is cited, in accordance with accepted academic practice. No use, distribution or reproduction is permitted which does not comply with these terms. 